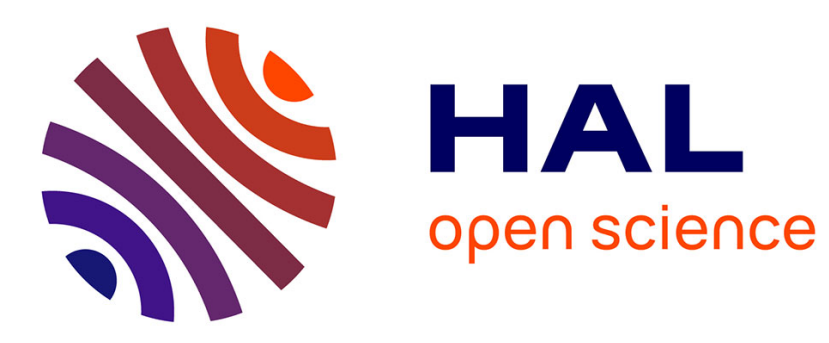

\title{
SME Buying Behaviour: Literature review and an application agenda
}

Emre S. Ozmen, M Atilla Oner, Farzad Khosrowshahi, Jason Underwood

\section{To cite this version:}

Emre S. Ozmen, M Atilla Oner, Farzad Khosrowshahi, Jason Underwood. SME Buying Behaviour: Literature review and an application agenda. Marketing Review, 2013, 13 (2), pp.207-227. halshs01200695v1

\section{HAL Id: halshs-01200695 https://shs.hal.science/halshs-01200695v1}

Submitted on 21 Sep 2015 (v1), last revised 5 Jul 2018 (v2)

HAL is a multi-disciplinary open access archive for the deposit and dissemination of scientific research documents, whether they are published or not. The documents may come from teaching and research institutions in France or abroad, or from public or private research centers.
L'archive ouverte pluridisciplinaire HAL, est destinée au dépôt et à la diffusion de documents scientifiques de niveau recherche, publiés ou non, émanant des établissements d'enseignement et de recherche français ou étrangers, des laboratoires publics ou privés. 


\section{SME Buying Behaviour: Literature review and an}

\section{application agenda}

SMEs have been recognized as important actors of commercial activity, especially in the second half of the 20th century. Although understanding customer potential has been named a top priority among many sectors, we have a limited body of knowledge regarding SMEs' buying behaviour. Many studies and industry practices frame the context within corporate or individual buying behaviour, however few researchers mention SMEs, and whenever they do, they tend to consider them as small versions of big enterprises. A holistic approach enables an extensive review of the literature, including some studies that focus on Turkey, and proposes a deductive application agenda. Although SMEs are categorized into "normative" or "conservative" buyers, the lack of application makes this dichotomy untested. An adopted unified model can be used for further research. A validated model can not only provide insights into SME buying behaviour, but also potentially open discussion on unnecessary distinctions between corporate and individual buying behaviour models. The paper also challenges the possible reasoning behind the lack of interest in SME buying behaviour, and scrutinizes a comprehensive knowledge base for exploratory application.

Keywords - SMEs, buying behaviour, marketing to SMEs, need driver 


\section{Emre S. Ozmen}

The University of Salford,Greater Manchester, M5 4WT, UK

e.s.ozmen@edu.salford.ac.uk

+441612955000

\section{Atilla Oner}

Associate Professor and Director of Management Application and Research Center (MARC)

Yeditepe University, Istanbul, 34755,Turkey

maoner@yeditepe.edu.tr

+90216578 1637

\section{Farzad Khosrowshahi}

Professor and Head of the School of Built Environment and Engineering

Leeds Metropolitan University, Leeds, LS1 3HE, UK

f.khosrowshahi@leedsmet.ac.uk

+441138129165

\section{Jason Underwood}

Assistant Professor and Director of Postgraduate Research Programme Admissions \& Training The University of Salford,Greater Manchester, M5 4WT, UK

j.underwood@salford.ac.uk

+441612956290

[Corresponding author: Emre S. Ozmen, e.s.ozmen@edu.salford.ac.uk] 
EMRE S. OZMEN has worked in New York, Kiev and Istanbul with various regional management responsibilities in ICT sector, including companies Microsoft and Intel. He is currently with The University of Salford, UK. He is expecting his PhD degree, with 'SME Buying Behavior' thesis, by the end of 2012. Other research interests include marketing and strategy-program-product-project management disciplines. He speaks English, Turkish, French and basic Russian. Please address correspondence to Emre S. Ozmen, The University of Salford, Greater Manchester, M5 4WT, UK. [email: e.s.ozmen@edu.salford.ac.uk]

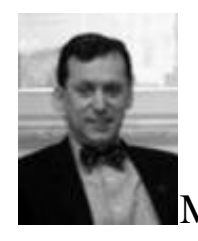

M. ATILLA ONER is Associate Professor of Production and Operations Management and Director of Management Application and Research Center (MARC) at Yeditepe University, Turkey. He is in the editorial board with International Journal of Innovation and Technology Management. He currently runs SME Polyclinic Program to assist family companies in Turkey. Please address correspondence to M. Atilla Oner, Management Application and Research Center, Yeditepe University, Istanbul, Turkey. [email: maoner@yeditepe.edu.tr]

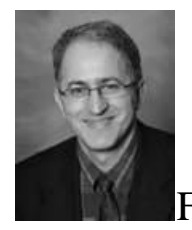

FARZAD KHOSROWSHAHI is Professor and Head of the School of Built Environment and Engineering at Leeds Metropolitan University, UK. Prior to LMU, he was Director of CIT at The University of Salford. On further 20 occasions, he has served as the 
visiting professor and invited speaker at several institutions across the globe. He is currently a Class 1 Visiting Professor at the University of Lyon - France. He has expertise in financial forecasting, as well as digital business in construction SMEs. Please address correspondence to Farzad Khosrowshahi, School of Built Environment and Engineering, Leeds Metropolitan University, Leeds, LS1 3HE, UK. [email: f.khosrowshahi@leedsmet.ac.uk]

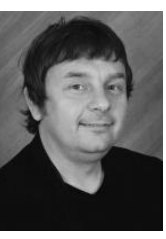

JASON UNDERWOOD is Assistant Professor and Director of Postgraduate Research Programme Admissions \& Training at The University of Salford, UK. He currently serves as Editor-in-Chief with International Journal of 3D Information Modeling. Prior to IJ3DIM, he was in editorial board of several journals with IGI-Global (PA, USA). Besides construction informatics and education, he has expertise ininterpretive structural model with prioritizing variables of SMEs. Please address correspondence to Jason Underwood, The University of Salford, Greater Manchester, M5 4WT, UK. [email: j.underwood@ salford.ac.uk] 


\section{Introduction}

The majority of relevant sources in extant literature and many sectors including technology analyse consumer buying behaviour according to two domains: business customers and individual customers. For business customers, it is easy to see organizational buying behaviour as the primary topic, whereby proof of a concentrated area is obtained by reference to corporate ${ }^{1}$ customers rather than small and medium enterprises $\left(\mathrm{SMEs}^{2}\right)$ (Sheth, 1973; Webster \& Wind, 1972). Wilson (2000) has summarized the misleading distinction behind previous models and offered a unified model;however, the application side of the issue remains premature.

Strategy is one of the most important indicators that sets short- and long-term success patterns for sustainable organizational development (Oner, 2004). Market strategy is the main premise of marketing management(where marketing is an important function in the organization), and partitions the market into homogeneous groups based on needs, buying patterns and consumption behaviours (Kotler, 1988). If a company does not understand its customers relative to market opportunities, the odds of marketing strategy success, no matter how clever, unique, or well executed, are greatly diminished (Silk, 2006).

However, literature including books such as Kotler's Marketing Management (1967), Pride and Ferrell's Marketing: Basic Concepts and Decisions (1983) and Silk's What is Marketing (2006) do not include any specific sections regarding marketing to SMEs. Similarly, there is no specific information on SME behaviour and its buying derivatives (Ozmen, Oner \&Khosrowshahi, 2012).

According to Wilson, the most axiomatic of these potentially distorting demarcations can be that between organizational and consumer buyer behaviour, founded on the apparent assumption that

\footnotetext{
${ }^{1}$ Yale Law Journal defines SMEs as right-and-duty-bearing units, as entities instead of persons (Dewey, 1926).

${ }^{2} \mathrm{~A}$ major group of the corporate world; companies below 250 employees or $€ 50 \mathrm{M}$ annual revenue (EUC, 2003).
} 
consumers buy as wilful individuals while organizations purchase as a rational group, ignoring the habitual, intuitive and experiential behaviour of purchasing managers and subordinates as uniquely idiosyncratic individuals. This distinction between "buying" or "purchasing" and "procurement" is itself indicative of the dichotomized approach and conceals a nest of implicit assumptions about the relative idiosyncrasy and professionalism of these behaviours (Wilson, 2000).

SMEs have been recognized as important actors of commercial activity, especially in the second half of the 20th century ${ }^{3}$. In Europe, SMEs comprise $99 \%$ of all firms and employ 75 million people (European Commission, 2003). Because of the dominance of small companies and unrecorded activities (especially in developing countries ${ }^{4}$ ), we cannot fully treat SMEs as corporate business customers (Hankinson, 2000). On the other hand, SMEs are not individual customers either, since they do run some type of revenue-generating business.

Turkey’s public SME support agency is KOSGEB, established in 1990. KOSGEB and DIE, the Statistics Institute of Turkey, map SMEs as follows (DIE, 2011):

- General trade, manufacturing and construction sectors have the highest number of employees $(71 \%)$.

- Excluding agriculture, there are 2 million companies; $46 \%$ are noted as general trade, $14 \%$ manufacturing/production, and $8 \%$ construction (more than half are real estate).

- $80 \%$ of companies are sole proprietorships; limited firms account only for about $15 \%$ (such a low number - even in limited companies - introduces difficulties with respect to following unrecorded activities).

\footnotetext{
${ }^{3}$ Academic search engines yield less than $1 \%$ of all articles about "SMEs" in the first half of $20^{\text {th }}$ century, whereasthis equatesto $7 \%$ for "corporate business" for the same period. In other words, 99\%+ of SME-related articles come from after 1950.

${ }^{4}$ In Turkey, $94 \%$ of companies have less than 9 employees, and $80 \%$ of companies are sole proprietorships (DIE, 2011)
} 
- The average number of employees for each is: 3.4 for the total, 2.4 in general trade, 7.9 in manufacturing/production, and 4 in construction, where the average of these leading sectors is almost equal to general trade.

Understanding customer potential is a top priority in many sectors, and easy adaptation is paramount in models used in various countries. Assuming SMEs worldwide have the same ability to respond, however, there are surprisingly few studies about the imperative starting point, which is "understanding SME buying behaviour". This study tests, rather than builds, theory. Preliminary research questions can be summarized as follows:

- How do SMEs prioritize their needs?

- How do SMEs buy in terms of timing, finance and sales points?

- Is there any interaction between needs characteristics and investment characteristics in terms of response time, preferred payment model, preferred sales channel and preferred brand level?

These questions highlight the relationship between"need" itself, the meaning that SMEs give to this need, and the attributes associated with the moment of purchase. Filling the possible knowledge gap can serve buying-behaviour researchers, marketers, policy makers and, most importantly, SMEs themselves.

The nextsection aims to scrutinize the buying behaviour boundaries for both the departures' and yielding models' perspectives. At this stage, an extensive literature review was conducted from the very beginning of the buying behavior concept, looking back to the 1920 s at some points. Although no distinctive information on SME buying behaviour can be found, it was reached to 
Wilson's attempt which unifies the polarized edges, which is also the basis for a carrier model including an application agenda.

\section{Boundaries of buying behaviour}

From a holistic perspective, according to The Chartered Institute of Marketing, understanding buying behaviourinvolvesa consideration of the needs of the customers- both individual and corporate - as well as what motivates them to purchase ${ }^{5}$. Buying behaviourincludes a series of steps from the need identification to the moment of purchase. Kotler (1988) defines buying behaviour as a study of what, when, where, how and how often people buy a product (e.g. a good or service).

As a general frame, factors affecting the steps defining buying behaviourhave beencategorized under external and internal stimuli (Sandhusen, 2000). External factors consist of economy, politics and infrastructure (Zaltman, 1983), whereas internals (Kotler and Armstrong, 2006) include characteristics of the audience (cultural components) and its needs.

From this perspective, there are various buying behaviour models that bring the steps - from the purchased item to the moment of purchasing - and the various factors within buying behaviour together (Peter and Olson, 1993; Baker and Hart, 2003). However, based on the preliminary literature review, the vast majority of models remain selective in terms of audience; in other words they are usable either for individuals (Goodhart, Ehrenberg \& Chatfield, 1984; Christopher, 2001) or for corporate customers (Sheth, 1973; Jacob 2006).

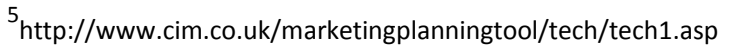


There are few model researchers for SMEs. Although researchers consider SMEs to be a natural part of the corporate segment, they strongly criticize corporate models in terms of their incorrect groundings, which are based, for instance, on adoption seeking (Ellegaard, 2006), strategic purchasing, heavy-industry-based supply chain, and procurement procedure domains (Pressey, 2009). However, these criticsdo notattempt to offer a new model or application framework.

Having considered all the antecedents, it is expected that a deeper literature review will help to provide more background on the context in terms of:

- Environmental stimuli (economic/political, demographic, technological)

- SME characteristics

- Needs assessments: why do SMEs buy? (including characteristics of their needs/investments)

- Buying attitude

- Model assessment: what are the characteristics of SMEs' buying behaviours?

\section{Environmental stimuli}

Although support exists for the argument that there is no relationship between economy and politics (Zizek, 2008), this is not the case in Turkey (Onur, 2004). Demographics such as age, gender, education, years in business and lifestyle (e.g. publications read, technology used, and relationships with competition) are other commonly-considered attributes.

Philosophical framework 
Plato noted that belief is to be distinguished from knowledge (Jowett, 2008). As a follower of Plato, Nozick (1981) suggested that continuous tracking of the truth is the path to seeking knowledge. According to Gettier (1963) and Weinberg (2001), epistemological problems depend on culture and audience. Knowledge is useful and truth can only help to shape it; truth is important, but not always. A deductive logic exercise to illustrate this can be outlined as follows: if you see products through a customer's eyes, truth is not always necessary since customers even vendors - may not get hurt from not knowing and/or applying the truth. If the sample is big enough and customer beliefs are equal to knowledge, truth has no natural effect on knowledge (i.e. there is no demand for truth). If vendors benefit from a customer's current beliefs, they will not want the truth to be included as part of customer knowledge. The possibility of customer beliefs remaining as knowledge - without truth - thus increases.

According to traditional logic, vendor beliefs, rather than stakeholder beliefs, are a part of knowledge. However, knowledge does affect vendors negatively. If a vendor does not know customer beliefs and if the vendor's beliefs are part of his/her knowledge and reality, the vendor will lose money because he/she will miss the point of how to address customer potential.

In sum, customer knowledge without truth may not hurt customers (including vendors), but a vendor's knowledge moving toward truth, and his/her own beliefs held over customer beliefs, can hurt the vendor. Customer beliefs and knowledge may not care about the truth, but vendors cannot use knowledge, even the truth, without considering customer beliefs instead of their own. This is why customer belief is the basis for buying behaviour, and understanding it is therefore vital to building a marketing strategy (Sandhusen, 2000).

\section{Characteristics of SMEs}


Culturally, SMEs are not small versions of big companies; they have distinct backgrounds (Ellegaard, 2009). Culture is considered differently in terms of inter-country comparisons, and there are as many SME cultures as there are world cultures.

Goffee and Jones' (1996) model led to one of the most extensive studies in Turkey within this context. Replicating this model, Toprak (2007) conducted an extensive series of interviews with 164 people to probe the typology of Turkish SMEs. The results suggested that the majority of respondents perceive themselves to be part of a communal culture. With regards to SMEs, the characteristics identified were as follows:

- Shared values

- Close relationships, both socially and professionally

- Unconditional respect for father-figure authority

- Need for hierarchies defined by the owner; employees are similar (Toprak, 2007)

- Management style of the boss forms organizational culture (Sargut, 1994; Toprak, 2007)

- Trust is valued more than knowledge (Bilgin, 2007)

- Less confident than they look (Bozkurt, 2011)

- Fear of losing prestige or looking weak (Bozkurt, 2011)

- SME culture in Turkey reflects country culture (Simsek, 2006)

In terms of organizational culture, systems and procedures:

- Ownership and general management structure can be summarized as owner-managers who dominate management and all crucial decisions (Figure 1). Lack of human resources and 
specialists is a likely prerequisite to being an SME, especially one that is on the small ${ }^{6}$ side (Arend\& Wisner, 2005). Limited capital structure (Romano,Tanewski\&Smyrnios,2000), lack of trust (Tatiana, Bojidar\& Ivan, 2007; Kautonena,Zolinb, Kuckertzc\&Viljamaad, 2010), and loyalty to select vendors (Madill et al., 2002) are other characteristics.

- Customers can be summarized as local with minimal international experience. Closerelationship-, network-based business is likely to be key (Gilmore, Carson \& Rocks, 2006; Niall, 2010; Ceci\&Lubatti, 2011).

- $\quad$ Systems and procedures can be summarized as simple yet adequate (Supyuenyong, Islam \& Kulkarni, 2009). They do not have the luxury of dealing with formal processes because they lack time and do not find these to be necessary. Not having a sophisticated system working behind them does not mean they lack competency. However, many resources note this as a limitation. Although it is important for behaviourists, this may not be a factor for marketers; it may only be an opportunity to understand how to treat them.

Figure 1 Small company owner-managers management representation (Hankinson, 2000)



\section{Needs assessment}

\section{Characteristics of SMEs' needs}

${ }^{6}<50$-employee companies are defined as "small", and this accounts for the vast majority of both SMEs and all companies (EUC, 2003). 


\section{Need drivers}

Purchasing is an action undertaken to fulfill a need. With respect to fulfilling the need, need drivers are motives but are not necessarily motivational concepts (Mahatoo, 1989). Motivational boundaries are a factor in building the motive, and practical and crucial information for behaviourists includes identifying the motives, or the customer's need drivers. A starting point could be to learn how customers position products on a driver basis. Is the source tangible, intangible or based on personal interest? The way in which they conduct the buying action could rely on this, rather than the need itself. Without knowing the meaning behind the purchase, it is difficult to obtain any real knowledge about it.

According to many researchers (Nicosia \& Mayer, 1976; Shaw, Giglierano\&Kallis, 1989), intangibility cannot be applied only to individuals, and cannot explain consumer buying behaviour alone. Likewise, tangibility not only applies to organizations, and cannot be used to explain organizational buying behaviour alone (Smith \& Taylor, 1985; Rushton \& Carson, 1989). There are multiple tangibility levels behind investments; therefore, the outcome of SME needs drivers is as follows, while the possible correlation between consumer approaches is remarkable (Wilson, 2000):

- High tangibility; must have

- Moderate tangibility

- Low or no tangibility/intangibility; nice to have

Purchase significance 
Purchase novelty is an essential factor when defining the conduction of need characteristics (Robinson, Faris\& Wind, 1967). Buy class theory includes three differentiation levels:

- Is this a new task?

- Is this a modified rebuy?

- Is this a straight rebuy?

The center of need leverage is based on frequency, which also demonstrates need continuity: is it a one-time-purchase or is the perceived significance routine rather than exceptional (Wilson, 2000)?

In Turkey, the product renewal period is shortest for cellular phones ( 2.5 years), with computers (3 years) and televisions (6 years) close behind (Radikal Newspaper, 2010). To define need characteristics, the purchase significance of the need, not just the need driver, plays an important role; the distinction among combinations is therefore more understandable. According to Robinson, the purchase significance of the need can be (Robinson et al., 1967):

- Exceptional; rare

- Moderate

- Routine; returning need

\section{Characteristics of SME investments}

There is a long-standing debate among academics and practitioners concerning the differences between goods and services in terms of behaviour (Rushton \& Carson, 1989). Although 
investments vary from human resources to the trivial, concentration here relies on marketability; in other words, goods or services with a product viewpoint.

Service characteristics (Rushton \& Carson, 1989) are intangible, heterogeneous, perishable, and inseparable from production and consumption (Figure 2).

Figure 2 Product-based tangibility representation (Rushton \& Carson, 1989)

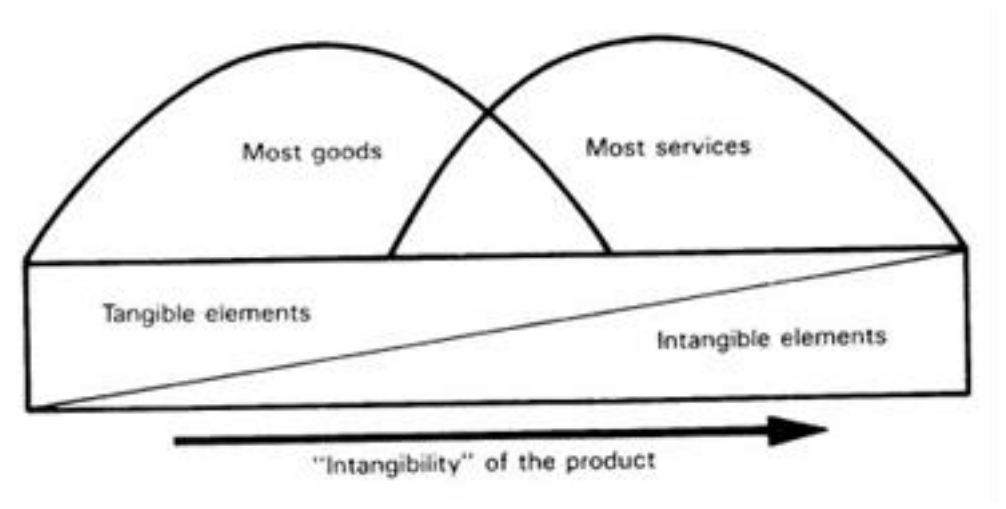

The variables of services (Rushton \& Carson, 1989) are intangibility in general (cannot touch, taste, smell, see), heterogeneity (cannot be standardized in the way goods can), perishability (cannot be stored; if it is not used when available then the service capacity is wasted), inseparability of production and consumption. These intangible elements make the procurement hard to evaluate, whereas this is a relatively new field to focus on.

\section{Buying attitude}

Can a homemaker be a rational purchaser? If not, how can the detail-oriented purchases of homemakers - even for the most trivial everyday needs - be explained? This consumer group may offer the best example in terms of rationality, since these roles cannot be separated. 
Can corporate customers be impulse buyers? Can irrational reasoning schemes be also important (Rantapuska\&Ihanainen)? If not, how can therapeutic shopping intentions of consumers be explained (Wilson, 2000)? Wilson (2000) offers some examples: corporate jets and luxury company cars, golf resorts for offsite meetings, the Star Wars Defensive Satellite Program; similarly, new office furniture based on fashion rather than function, inefficient use of CRM/ERP/MRP software, countless annual employee get-togethers, HP Palm acquisitions and sales after one year, big management consultancy money spent on human resources reorganization of multinational companies every three to five years, etc. Kotler and Armstrong (2006) not only state that"once the consumer has decided to execute a purchase intention, he/she will make up to five purchase sub-decisions", but also frame the fundamentals of this.

\section{Model assessment}

\section{Individual customers}

Copeland's (1923, 1924b) attempts addressed the complete picture, including not only rational but also emotional and instinctive consumer buying tendencies. Even Maslow (1943) was inspired within this context. Followers such as Martineau (1955);Goodhart et al. (1984), with their Drichlet Model; and Christopher (1989) had similar intentions to focus on the consumer perspective. Peter and Olson (1993) position consumers as individuals, stating that: "Interactions between the people's emotions, moods, affection and specific feelings is called consumer behavior, in other words in environmental events in which they exchange ideas and benefits each called consumer behavior." 
Kotler's (1988) definition similarly includes personal and organizational consumers. Sandhusen's (2000) Black Box Model is comprehensive, emphasizing all possible boundaries as factors, beyond need. However, no application of SMEs is considered a part of the corporate world. Extant studies concentrate on changes in the psychological centre of gravity within the buying context and the rising importance of impulse buying, rather than a general framework (Park et al., 2001). It seems that consumer behaviourists switch the mindset from the objective/absolute positioning of Ries and Trout to subjective/conditional positioning for consumers aged 25 to 45 , an age when people tend to focus on self-actualization, rather than materialistic-inspired needs (Wolfe \&Sisodia, 2003). In the consumer world, everyone seems to be a part of each consuming stage set forth by Maslow (1943), at least once in their life.

\section{Corporate customers}

Copeland's (1924a) industrial goods papers include nothing but derivatives of rational motives for corporate customers. Generally, industrial customers are not considered end-users, but rather have been primarily seen as raw-material or inventory purchasers. Because of a lack of SME interest, tasks, procedures, and processes relating to purchasing have been the primary points of consideration (Kennedy, 1982). Buyer-seller, relationship-based model research is the center of focus for studies by Jacob and Ehret (2006), where the common understanding is that over the last 25 years, sellers have come to act like buyers and vice versa. Considering vendors as partners (even customers) is becoming increasingly important due to the win-win possibilities of long-term business opportunities.

Despite the fact that loyalty has mainly been considered with reference to the corporate world, SMEs have long used loyalty as a practice for building relationships (Madill et al., 2002). As a 
follower of prospect theory, Jacob (2006) explores empirical and observable decision behaviour with a complete range of possible outcomes and their respective possibilities, rather than norms and optimal decision behaviour. However, it is difficult to find an application for practitioners of SME customers.

For adoption seekers, it is easy to identify the central phenomenon that could be scrutinized: namely strategic purchasing (Dobler, 1965; Dollinger\&Kolchin, 1986) or purchasing adoption (Park \& Krishnan 2001; Mudambi, Schrunder\&Mogar, 2004). Researchers espouse three reasons behind the importance of purchasing adoption for understanding SMEs, with reference to reasons rather than results: smaller companies do not place a high priority on considering the supplier's viewpoint, which may lead to suppliers having a lack of trust of SMEs, and inflexible requirements. The question is whether suppliers want to embrace SMEs. If the answer is positive, the majority of the issues stated above will be handled on the supplier's side. Thus, everything else is moot since suppliers, vendors, and sellers could not dictate anything to SMEs or other customer segments. Sometimes the intention is to treat SMEs like children who know little to nothing and constantly need help with everything; this is unhelpful, especially if the audience is a supplier, vendor or seller. On the contrary, SMEs are much more capable of running their businesses in changing environments than perceived (Ellegaard, 2009).

Despite the initial expectation, other researchers conclude the opposite, perceiving that SMEs cannot be a target for strategic purchasing because purchasing is the informal domain of the SME owner (Pressey, Winkelhofer\&Tzokas, 2009). This paradigm agrees with supporters like Carr and Pearson (1999) (flexibility), Quayle (2000) and Ramsay (2001, 2008) (size asymmetries), Zheng, Caldwell, Harland, Powell, Woenrdl and Xu. (2004) and Zheng, Knight, 
Hardland, Humby and James (2007) (small quantities due to cash flow concerns); all agree that limitations do not necessarily indicate limited management sophistication.

Motive researchers examining corporate entities (rather than consumers) assume that subjects operate on a rational/tangible axis. Although not clearly stated, this assumes that intangible drivers do not exist or are not an important enough factor to be mentioned. Many studies focus on rationality, examining factors accordingly. One controversial attempt by Urwiler and Frolick (2008) applies Maslow's theory to the technology needs of companies. Here, five variables are derived from Maslow, examining the process from commodity to innovative IT.

Although understanding of SME purchasing practices has improved over the years, there are notable gaps (Ellegaard, 2009). It is safe to say that there is a need for improved understanding of SME purchasing behaviours and competencies, particularly in terms of informality. With respect to global purchasing topics, Quintens, Pauwels and Matthyssens (2006) suggest that the field is in need of more profound and longitudinal case-based studies that allow in-depth exploration of the phenomenon; the current conceptual framework is superficial and has been explored poorly. Advanced theory testing, including structural equation modeling, is beneficial, and failing to offer a model will not facilitate the achievement of that purpose. Other points have been put forth as follows:

- Strategic purchasing is not a significant factor toward understanding SME buying behaviour. Searching for an answer to "what is a need driver?" rather than "what is a procurement procedure?" can help to explore more useful information for both parties (Moller \&Torronen, 2003).

- Because of the complicated nature of supplier/procurement relationships, it is reasonable to scrutinize purchasing adoption (Kaynak, Tatoglu\& Kula,2005). However, simple 
vendor/buyer transactions also occur, and this is the area from which the majority of commercial activity comes. Attention could be directed to SMEs as end-users of commodities for internal use, rather than buyers of raw materials for use in manufacturing, inventory or resale.

- Beyond purchasing in SMEs or marketing in SMEs (Brooks \&Simkin,2011;Jones \& Rowley, 2011), the word "adoption" is widely used, especially with respect to ICT adoption by SMEs (Tambunan, 2007; Yu \& Tao, 2009). The majority of researchers consider companies and SMEs as end-users on a "to be adopted" basis, rather than "already adopted" (Galende\& De la Fuente, 2003; Viljamaa, 2011). However, the question of how they respond in terms of preferred channels, timing, payment models and brand level is worth exploring in order to open the SME black box - as a customer -in lieu of supplier evaluations and capability factors or how SMEs can market their goods (Pressey et al., 2009).

- An important reason could be using the term "SME", while doing the research with only medium sized companies ${ }^{7}$ (Kendall, Tung, Chua, Ng\& Tan 2001). However, unlike small companies, medium-sized companies do not dominate SMEs and cannot generalize results on behalf of SMEs(EUC, 2003).

- Reviewed papers use ICT as the subject of specific ICT investment; there is little mention of popular ICT and other investments such as furniture, cars or commercial light vehicles (Palmer, Ellinger, Allaway\& D’Souza,2011).

Since there is no final word in this sparsely examined field, this topic deserves more attention due to its vast potential, especially when considering comparative analyses among sectors.

${ }^{7}$ From 50- to 250-employee-sized companies (EUC, 2003). 
Pressey et al. (2009) state that their study was first applied to an SME context; this study raises the same issue within a different framework, through application.

\section{Alternative models}

Starting from Maslow (1943), many models have focused on buying behaviour. Following Maslow's study, physiologists like Max-Neef (1992) expanded the model to include nine elements; Jager, Janssen, de Vries, de Greef and Vlek (2000) expanded it into four modes of cognitive processing; and Twomey and Cadman (2002) adapted it into agent-based models, researching relationships between consumer perceptions and characteristics. Brunswik's Lens Model (1952) likely inspired Hauser and Koppelman (1979) and many others; however, applications to SMEs remain unexplored.

Addressing alternative paradigms in operational research, Meredith, Raturi, Gyampah and Kaplan (1989) use axiomatic and artificial reconstruction axis models. Bleicher's (1991) Integrated Management Model (IMM) similarly offers multi-axis approaches to management. Afuah and Bahram (1995) use value-added chains and innovation radicalness axes to examine correlations among variables. Similarly, SME flexibility and JIT adoptability interactions are the focus for Abdul-Nour, Drolet and Lambert (1999). Beard (2002) examines technology management using perceptions and size of the company. Developed by Kumar, Venkatesan and Reinartz (2006), Nobel Prize winner McFadden's model examines customers using product type and timing relationships. Bleicher (1991) developed the St Gallen Management Concept, using management research where the concept was built on management functions defined as forming, steering and developing. Alsan and Oner (2004) also use the model in integrated foresight management (IFM). 


\section{Modelling buying behaviour of SMEs}

Robinson et al.'s (1967) Buy Class model, based on purchase novelty, is widely promoted. However, purchase novelty is not the only factor determining the importance given by organizations. Especially in SMEs, the only decision-maker is often the owner, directly or indirectly. Similarly but using different expressions, Webster and Wind (1972), Sheth (1996) and Wensley (1997) offer rationality as a natural assumption in organizations. Those negligent researchers of bases besides rationality look toward distinction seekers among organizations and individuals. The common accepted paradigm is that irrationality only exists in consumer buying behaviour. The contrary is also unembraced, and the majorityof this group of researchers does not even declare objections, considering irrationality or intangible needs as a negligent effect in organizations.

According to Wilson (2000), if rationality is the signature of organizations, the question remains as to how the best examples of rationality - even where informal, such as homemakers' daily spending - can be explained? If we accept that intangibility (as a need driver) is a factor for organizations as well, can we assume that the distinction between consumer and organizational buying behaviour models is negligible? Researchers' negligence with respect to recognizing the distinction between individual and organizational buying behaviours is increasing, creating a situation that focuses on application rather than new model research. Foxall (1981), Fern and Brown (1984), Smith and Taylor (1985), Shaw et al. (1989), Shipley and Howard (1993), Wilson (2000), Pickton and Broderick (2001), Wilson and Woodside (2001), Coviello and Brodie (2001) and Jaakola (2007) state that differences between consumer and organizational buying behaviours are relative rather than absolute. Shaw et al.(1989) sum this up as follows: "Are we to 
think that an executive makes business buying decisions based on quantifiable product characteristics and yet makes personal buying decisions based on intangibles?".

Similarly, and based on previous studies such as that by Smith and Taylor (1985), Wilson (2000) promotes rationality-irrationality and tangibility-intangibility for needs that do not belong to only one side. Each party has its say, whether individual or organizational. Pickton and Broderick (2001) suggest that human beings by their nature cannot change in the manner of "robots" (i.e. by toggling a switch) when acting in business situations. Coviello and Brodie (2001) state that the organizational-consumer buying behaviour dichotomy is not relevant when describing and analysing purchasing decisions. The reasoning behind whether to use rationality or intangibility for need drivers is more important, since the current situation has been observed many times in groups, but no application exists for organizations and, in particular, SMEs are assumed to be similar to individuals.

Underlying the views presented above, Fern and Brown's (1984) thesis represents extreme examples rather than normative and generalizable models. If the level of rationality behind the buying decision is a factor that can be observed, the extreme example situation decreases in intensity. A normative and generalizable model can be linked to Alsan and Oner's (2004) IFM model, seeking foresight under an operational research umbrella. Why, then, can normative and generalizable models not be used for buying behaviour? Wilson (2000) not only offers an integrated model, but promotes its wide use. Although his proposal is designed to be applied to organizational buyer behaviours, he asks why it cannot also apply to consumer purchasing. He sees no obvious reason not to pursue this approach.

Even the reverse could be a topic of discussion, since Wilson (2000) suggests: "If a unified model of purchase classifications could be developed there seems no compelling reason to 
perpetuate an unnecessary distinction between organizational purchasing and consumer purchasing".

Figure 3 Cube adapted from Wilson (2000)

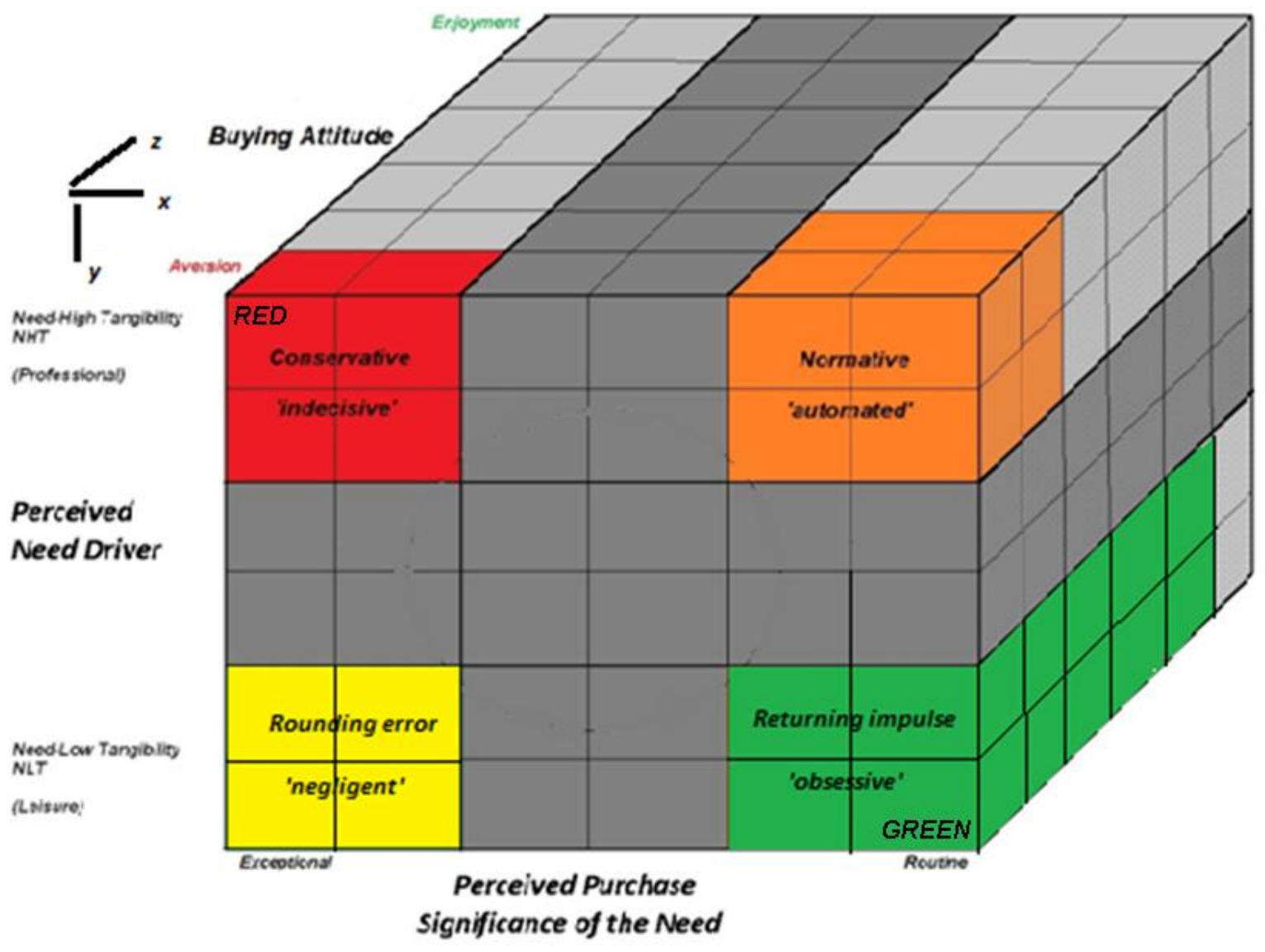


Figure 3 summarizes the points stated in this section, extending answers for need assessment and buying attitude questions in the boxes for each product ${ }^{8}$.

- Organizations also buy within the low tangibility need driver (y-axis);

- Higher purchase significance (x-axis) positively influences buyer attitude enjoyment (z-axis);

- Lower tangibility need drivers (y-axis) positively influence buyer attitude enjoyment (z-axis) (Wilson, 2000).

It is up to SMEs how the boxes are perceived for each product, for instance whether they are seen as high or lowneed tangibility (y-axis), as well as routine or exceptional procurement (xaxis). Any combination among axes is possible; SMEs only need to choose the best answer.

\section{Conclusion}

SMEs are powerful players in the economy,and many aspects can be attributed to them, including the idea that SMEs are customers, which is the focus of the study. Studies and industry practices are conformist, and assume SMEs to be absolute rational buyers. Although customer potential has been named a top priority among many sectors, there is a limited body of knowledge for SMEs' buying behaviour. The research problem pointed tothe lack of either a buying behaviour model for SMEs, or its application. This suggested a context of possible gaps between corporate and individual buying models or frameworks. All review models are positioned either in the individual or the corporate segment. Only Wilson's model is not polarized, and serves as an attempt to unify different audiences.

\footnotetext{
${ }^{8}$ Tea, Property, Furniture, Vehicles, Communication Tech., IT, Special Tech., TV, Insurance, Financial Services, Consulting, Ads.
} 
- Within an extended view, similar to buying behavior, marketing is also handled into two main arteries, either individual or corporate. The articles that include "marketing" and "SMEs" together are those that attempt to explore "marketing in SMEs", rather than "marketing to SMEs". The former asks"How can SMEs sell their goods?", rather than "How do SMEs buy?" which is the area of interest in this paper. In other words, unlike the latter, the marketing readiness or procedural improvements that SMEs' marketing operations need have been widely covered.

- As a relevant discipline, the procurement context is also reviewed in the light of SMEs. It is common in the literature to use the term "SME" while conducting research using only medium-sized companies. However, unlike small companies, medium-sized companies do not dominate SMEs and cannot generalize results on behalf of SMEs.

- Ultimately, because of the nature of supplier/procurement relationships, it is reasonable to scrutinize purchasing adoption for medium-sized companies. However, simple vendor/buyer transactions also occur, and this is the area in which the majority of commercial activity comes within small companies. Relevantly, it is also notable that this distinction prevents researchers from considering SMEs as end-users of commodities for internal use, rather than buyers of raw materials or resale items.

- It has been observed that procedural improvements in SMEs are the motives of many researchers, from either a procurement or marketing, or an IT deployment perspective, where the reason for this is that SMEs are treated as medium-sized companies, rather than tying inthe dominant segment of SMEs - i.e. small companies.

- It is noted that small companies have one owner, and any (purchasing) decision is made by her/him, whether formally or informally. The mother/father figure also determines the culture 
of the company in many respects. The literature suggests that a person cannot switch like a robot when acting in business situations. Therefore, from the perspectiveof a marketer, winning or losing them could mean winning or losing the homemaker, or the opposite could also be true.

The buying behaviour literature review in light of SMEs can therefore be summarized as follows (Figure 4):

Figure 4 Forces affecting buying behaviour

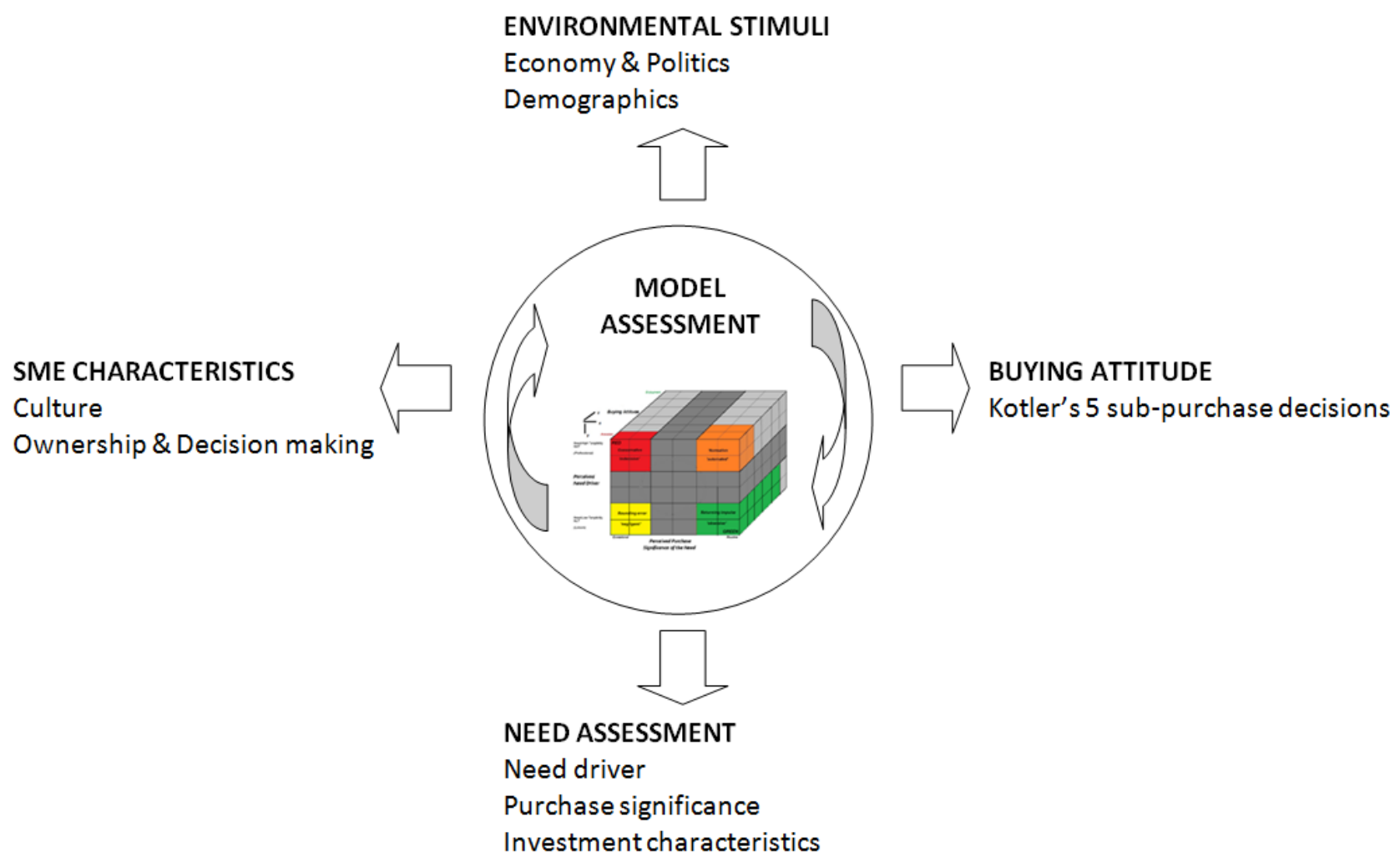




\section{Future directions}

The aim is to develop a buying behaviour framework for SMEs in Turkey. Filling this gap can serve buying behaviour researchers, marketers, policy makers and, most importantly, SMEs themselves.

Preliminary research questions have pointed out the relationship between "need" itself, the meaning that SMEs gave to this need, and the attributes associated with the moment of purchase. The discussion of this problem carries deductive roots and seeks an objective answer through positivist reasoning of the research questions.

Wilson's Cube has a positive correlation across the $\mathrm{x}, \mathrm{y}$ and $\mathrm{z}$ axes; therefore, a combined hypothesis may help in this research. From this perspective, quantitative techniques stand out, and thus hypothesis testing could be a better fit for future applications.

\section{Limitations}

The creation of an SME buying behaviourmodel and its application is a very premature field in the literature. Therefore, there are no clear directions or boundaries. The holistic view presented in this paper helps to further the journey of understanding SME buying behaviour in a generalized way. It suggests that SMEs are big enough to earn a model of their own, or at least an application which generalizes their buying behaviour. However, starting this research in the context of Turkey and not being able to validate it against other regions may potentially diminish the outcome, though the possibility of its being a frontier paper is also quite rewarding. 


\section{References}

Abdul-Nour, G., Drolet, J., \& Lambert, S. (1999). Mixed production, flexibility and SME, Computer and Industrial Engineering, 37(1-2), 429-432.

Afuah, A.N., \& Bahram, N. (1995).The hypercube of innovation.Research Policy, 25(7), 51-76.

Alsan, A., \& Oner, M.A. (2004). Comparison of national foresight studies by integrated foresight management model. Futures, 36(8), 889-902.

Arend, R., \& Wisner, J. (2005). Small business and supply management: Is there a fit?.Journal of Business Venturing, 20, 403-436.

Baker, M. J., \& Hart, S. (2003). The Marketing Book. Oxford: Butterworth Heinemann, 757-775.

Beard, J. W. (2002). Management of technology: A three-dimensional framework with propositions for future research. Knowledge, Technology and Policy, 351-373.

Bilgin, N. (2007). The institutionalization of management in the family firm: Example of Ankara SME (Mastersthesis). Istanbul: AtilimUniversitesi.

Bleicher, K. (1991). Das Konzeptintegriertes Management. Frankfurt: Campus.

Bozkurt, R. (2011). Zayifgoruntuvermemeveprestijkorkusu [online].Retrieved from http://istekobi.com/kobi-bilgi-merkezi/makaleler/.

Brooks, N., \&Simkin, L. (2011).Measuring marketing effectiveness: An agenda for SMEs.The Marketing Review, 11(1), 3-24.

Brunswik, E. (1952). The conceptual framework of psychology.International Encyclopedia of Unified Science, 1-10. Chicago, IL: University of Chicago Press.

Carr, A.S., \& Pearson, J.N. (1999).Strategically managed buyer-supplier relationships and performance outcomes.Journal of Operational Management, 17(5), 497-519. 
Ceci, F., \&Lubatti, D. (2011). Personal relationships and innovation diffusion in SME networks: A content analysis approach. Research Policy.doi: org/10.1016/j.respol.2011.10.003.

Christopher, M. (1989). 2001 - The existential consumer. European Journal of Marketing, 23(8), 80-84.

Copeland, M. (1923).Relation of consumers' buying habits to marketing methods.Harvard Business Review, 1(3), 282-289.

Copeland, M. (1924a). Buying motives for industrial goods, Harvard Business Review, 2(3), 303-318.

Copeland, M. (1924b). Consumer's buying motives. Harvard Business Review, 2(2), 139-153.

Coviello, N.E., \& Brodie, R.J. (2001). Contemporary marketing practices of consumer and business-to-business firms: How different are they? Journal of Business \& Industrial Marketing, 16(5), 382-400.

DIE-Statistics Institute of Turkey (2011), "IllerinveBolgelerinSosyoekonomikGelismislikSıralamasıArastırması”, $\quad$ accessed http://www.sp.gov.tr/documents/KSEP_2011-13.pdf www.dpt.gov.tr/DocObjects/Download/8143/2003-05.pdf.

Dobler, D.W. (1965). The challenge of proficiency in small company purchasing.Journal of Purchasing, 1(1), 53-61.

Dollinger, M.J., \&Kolchin, M.G. (1986).Purchasing and the small firm.American Journal of Small Business, 10(3), 33-45.

Ellegaard, C. (2006). Small company purchasing: A research agenda. Journal of Purchasing and Supply Management, 12(5), 272-283. 
Ellegaard, C. (2009). The purchasing orientation of small company owners.Journal of Business \& Industrial Marketing, 24(3/4), 291-300.

European Union Commission (EUC) (2003). Commission recommendation: Concerning the definition of micro, small and medium-sized enterprises. Official Journal of the European Union, L124, 36-41.

Fern, E.F., \& Brown, J.R. (1984). The industrial/consumer marketing dichotomy: A case of insufficient justification, Journal of Marketing, 48(2), 68-77.

Foxall, G.R. (1981). Marketing Behaviour: Issues in Managerial and Buyer Decision-making. Farnborough: Gower Publishing.

Galende, J., \& De la Fuente, J.M. (2003).Internal factors determining a firm's innovative behavior.Research Policy, 32, 715-736.

Gettier, E. (1963). Is justified true belief knowledge? Analysis, 23(6), 121-123.

Gilmore, A., Carson, D., \& Rocks, S. (2006). Networking in SMEs: Evaluating its contribution to marketing activity, International Business Review, 15(3), 278-293.

Goffee, R., \& Jones, G. (1996). What holds the modern company together? Harvard Business Review, 74(6), 133-48.

Goodhart, G.J, Ehrenberg, A.S.C., \& Chatfield, C. (1984). The drichlet: A comprehensive model of buying behaviour. Journal of Royal Statistics Society, 147(5), 621-655.

Hankinson, A. (2000). The key factors in the profiles of small firm owner-managers that influence business performance.Industrial and Commercial Training, 32(3), 94-98.

Hauser, J.R., \&Koppelman, F.S. (1979). Alternative perceptual mapping techniques: Relative accuracy and usefulness. Journal of Marketing Research, 16(4), 495-506. 
Jaakkola, E. (2007). Organizational or consumer buying behaviour? Purchase decision-making within professional consumer services. Marketing Theory, 7(1), 93.

Jacob, F., \&Ehret, M. (2006). Self-protection vs opportunity seeking in business buying behavior: an experimental study. Journal of Business and Industrial Marketing, 21(2), 106117.

Jager, W., Janssen, M.A., de Vries, H.J.M., de Greef, J., \&Vlek, C.A.J. (2000). Behavior in commons dilemmas: Homo Economicus and Homo Psychologicus in an ecologicaleconomic model. Ecological Economics, 35(3), 357-380.

Jones, R., Rowley, J. (2011). Entrepreneurial marketing in small businesses: A conceptual exploration. International Small Business Journal.29(1), 25-36

Jowett, B. (2008). Introduction, Analysis and Translation of Theaetetus by Plato.Retrieved from http://www.gutenberg.org/files/1726/1726-h/1726-h.htm

Khan, B. (2010, February 20). Product renewal period market research of Millward Brown.Radikal Newspaper.

Kautonena, T., Zolinb, R., Kuckertzc, A., \&Viljamaad, A. (2010).Ties that blind?How strong ties affect small business owner-managers' perceived trustworthiness of their advisors.Entrepreneurship \& Regional Development: An International Journal, 22(2), 189209.

Kaynak, E., Tatoglu, E., \& Kula, V. (2005). An analysis of the factors affecting the adoption of electronic commerce by SMEs: Evidence from an emerging market. International Marketing Review, 22(6), 623-640.

Kendall, J., Tung, L., Chua, K., Ng, C., \&Tan, M. (2001).E-commerce adoption by SMEs in Singapour.IEEE, 9, 1-10. 
Kennedy, A.M. (1982). Industrial buying behavior: A review literature and research needs. Management Decision, 20(1), 38-51.

Kotler, P. (1988). Marketing Management. Englewood Cliffs, NJ: Prentice Hall.

Kotler, P. \& Armstrong, G. (2006).Principles of Marketing (11th ed.). Upper Saddle River, NJ: Prentice Hall.

Kumar, V., Venkatesan, R., \&Reinartz, W. (2006).Knowing what to sell, when, and to whom.Harvard Business Review, 84(3), 131-136.

Madill, J.J., Feeney, L., Riding, A., \& Haines Jr., G.H. (2002). Determinants of SME owners' satisfaction with their banking relationships: A Canadian study. International Journal of Bank Marketing, 20(2), 86-98.

Mahatoo, M.H. (1989). Motives must be differentiated from needs, drives, wants: Strategy implications. European Journal of Marketing, 23(3), 29-36.

Martineau, P. (1955). It's time to research the consumer. Harvard Business Review, 33(4), 45-55.

Maslow, A. (1943). A Theory of Human Motivation. Brooklyn, NY: Brooklyn College.

Max-Neef, M.A. (1992). Development and human needs. In Ekins and M.A. Max-Neef (Eds.).Real Life Economics: Understanding Wealth Creation. London: Routledge, 197-214.

Meredith, J. R., Raturi, A., Gyampah, K. A.,\& Kaplan, B. (1989).Alternative research paradigms in operations.Journal of Operations Management, 8(4), 297-326

Milling, P.M. (2002).Understanding and managing innovation process.System Dynamics Review, 18(1), 73-86.

Moller, K.E., and Torronen, (2003). Business suppliers' value creation potential: A capability based analysis. Industrial Marketing Management, 32(2), 109-118. 
Mudambi, R., Schrunder, C.P., \&Mogar, A. (2004). How co-operative is co-operative purchasing in small firms? Evidence from UK engineering SMEs.Long Range Planning, 37(1), 85-102.

Nicosia, F.M., \& Mayer, R.N. (1976).Towards a sociology of consumption.Journal of Consumer Research, 3(2), 65-75.

Nozick, R. (1981). Knowledge and skepticism:Philosophical Explanations. Oxford: Oxford University Press, 172-178.

Oner, A.M. (2004).Perfect 3rd Sector Management Model. Istanbul: Bogazici University Press.

Onur, S. $\quad$ (2004).LiteraturdeEkonomi-PolitaIliskisi.IsGucEndustriIliskileriveInsanKaynaklariDergisi, 6(1-4), 191.

Ozmen, E.S., Oner, M.A., Khoshrowshai, F. (2012). How to Form the Knowledge that Marketers Need?: An Approach for Marketers to SME. Business Management and Strategy, 3(1), 61.http://dx.doi.org/10.5296/bms.v3i1.1850

Palmer, D.W., Ellinger, A.E., Allaway, A., \& D’Souza, G. (2011).A longitudinal examination of internet-based customer service system usage in small companies.Journal of Business \& Industrial Marketing, 27(1), 29-40.

Park, D., \& Krishnan, H.A. (2001). Supplier selection practices among small firms in the United States: Testing 3 models. Journal of Small Business Management, 39(3), 259-271.

Peter, J.P., \& Olson, J.C. (1993).Consumer Behavior and Marketing Strategy. Homewood, IL: Richard D Erwin.

Pickton, D., \& Broderick, A. (2001).Integrated Marketing Communications. London: Prentice Hall. 
Piercy, N. (2010).Improving the marketing-operations relationship: Case evidence from an internet small-medium-enterprise.The Marketing Review, 10(4), 333-351.

Pressey, A.D., Winklhofer, H.M., \&Tzokas, N.X. (in press). Purchasing practices in small-to medium-sized enterprises: An examination of strategic purchasing adoption, supplier evaluation and supplier capabilities. Journal of Purchasing \& Supply Management.

Quayle, M. (2000).Supplier development for UK small and medium-sized enterprises.Journal of Applied Management Studies, 9(1), 117-133.

Quintens, L., Pauwels, P., \&Matthyssens, (2006). Global purchasing: State of the art and research directions. Science Direct, 12(4), 170-181.

Ramsay, J. (2001). Purchasing's strategic irrelevance. European Journal of Purchasing \& Supply Management, 7(4), 257-263.

Ramsay, J. (2008). Purchasing theory and practice: An agenda for change. European Business Review, 20(6), 567-569.

Rantapuska, Y., and Ihanainen, O. (2008).Knowledge use in ICT investment decision making of SMEs.Journal of Enterprise Information Management, 21(6), 585-596.

Robinson, P.T., Faris, C.W., \& Wind, Y. (1967).Industrial Buying and Creative Marketing. Boston, MA: Allyn and Bacon.

Romano, C.A., Tanewski, G.A., \&Smyrnios, K.X. (2000). Capital structure decision making: A model for family business. Journal of Business Venturing, 16(3), 285-310.

Rushton, A.M., \& Carson, D.J. (1989). The marketing of services: Managing the intangibles. European Journal of Marketing, 23(8), 23-44.

Sandhusen, R.L. (2000). Marketing (3rd ed.). Hauppauge, NY: Barron's. 
Sargut S. (1994). KulturlerarasiFarklilasmaveYonetim.V Yayinlari, 1.Bolum, Ankara 84.

Shaw, J., Giglierano, J., \&Kallis, J. (1989). Marketing complex technical products: The importance of intangible attributes. Industrial Marketing Management, 18(1), 45-53.

Sheth, J.N. (1973). A model of industrial buyer behavior.Journal of Marketing, 37(4), 50-56.

Sheth, J.N. (1996). Organizational buying behavior: Past performance and future expectations. Journal of Business and Industrial Marketing, 10(3/4), 7-24.

Shipley, D. \& Howard, P. (1993).Brand naming industrial products, Industrial Marketing Management, 22, 59-66.

Silk, A.J. (2006).What is Marketing?. Boston, MA: Harvard Business Press.

Simsek, O. (2006). TUHIS.ZihniyetGirisimcilikve KOBI-Sosyolojilliskisi, 20(3/4), 64-74.

Smith, D., \& Taylor, R. (1985).Organisational decision making and industrial marketing.European Journal of Marketing, 19(7), 56-71.

Supyuenyong, V., Islam, N., \& Kulkarni, U. (2009). Influence of SME characteristics on knowledge management process. Journal of Enterprise Information Management, 22(1/2), 63-80.

Tatiana S.M., Bojidar S.G., \& Ivan M.M. (2007).The role of interpersonal trust for entrepreneurial exchange in a transition economy.International Journal of Emerging Markets, 2(2), 107-122.

Tambunan, T. (2007). Transfer of technology to and technology diffusion among non-farm small and medium enterprises in Indonasia. Knowledge, Technology \& Policy, 20(4), 243-258.

Toprak, M.A. (2007). Determining the corporate culture and an implementation in SMEs (Doctoral thesis).Istanbul University, Istanbul. 
Twomey, P., \& Cadman, R. (2002).Agent-based modeling of customer behavior in the telecoms and media markets.Info, 4(1), 56-63.

Urwiler, R., \&Frolick, M.N. (2008).The IT value hierarchy.Information Systems Management, 25(2), 83-88.

Viljamaa, A. (2011). Exploring small manufacturing firms' process of accessing external expertise.International Small Business Journal, 29(5), 472-488.

Webster, F.E., \& Wind, Y. (1972).A general model for understanding organizational buying behavior.Journal of Marketing, 36(2), 12-19.

Weinberg, J., Nichols, S., \& Stich, S. (2001).Normativity and epistemic intuitions.Philosophical Topics, 29(1-2), 429-460.

Wensley, R. (1997). The customer knows best: Does consumer marketing underestimate the intelligence of customer. Marketing Business, May, 61.

Wilson, D.F. (2000). Why divide consumer and organizational buyer? European Journal of Marketing, 34(7), 780-796.

Wilson, E. J. and Woodside, A. G. (2001). Executive and consumer decision processes: increasing useful sensemaking by identifying similarities and departures. Journal of Business \& Industrial Marketing, 16(5), 401-14.

Wolfe, D.B., \&Sisodia, R. (2003).Marketing to the self-actualizing customer.Journal of Consumer Marketing, 20(6), 555-569.

Yu, C.S., \& Tao, Y.H. (2009).Understanding business-level innovation technology adoption.Technovation, 29(2), 92-109. 
Zaltman, G., \&Wallendorf, M. (1983).Consumer Behaviour: Basic Findings and Management Implications. New York, NY: John Wiley \& Sons

Zheng, J., Caldwell, N., Harland, C., Powell, P., Woenrdl, M., \& Xu, S. (2004). Small firms and e-business: Cautiousness, contingency and cost-benefit. Journal of Purchasing and Supply Management, 10(1), 27-39.

Zheng, J., Knight, L., Hardlard, C., Humby, S., \& James, K. (2007).An analysis of research into the future of purchasing and supply management.Journal of Purchasing and Supply Management, 13(1), 69-83.

Zizek, S. (2008). The prospects of radical politics today.International Journal of Baudrillard Studies, 5(1), 77. 